\title{
The Influence of TPP on China and the Corresponding Countermeasures to Intellectual Property
}

Xiaoqing Feng ${ }^{* *} \&$ Zhixiao $\mathrm{Wu}^{* * *}$

Trans-Pacific Partnership Agreement (TPP), known as the 'economic' NATO Agreement dominated by the United States, will impose profound influence on the politics, economy, society and intellectual property system in China. There are deep-seated reasons why the US are extremely active to make TPP signed and why China is ruled out in the course of the negotiations. Since China has entered into the WTO, the domestic and international market is closely related, and TPP must have significant impact on China's international market. With regard to the influence, China shall take efficient measures to cope with, including: dealing with issues appropriately regarding its economic sovereignty, based on its own situations, promoting of negotiations on free trade agreement, keeping on improving the hard and soft power in intellectual property, fully taking advantages of "the Belt and Road Strategy" and exploring new market; and getting ready for constant adaptation to TPP rules and the like.

* This research project was supported by Training Support Program for Outstanding Middle \& Young Teachers, China University of Political Science and Law (CUPL); Milestone of national projects supported by National Social Science Foundation: "Researches of the theoretical system of intellectual property with Chinese characteristics" (Project Number: 11AZD047).

** Director \& Professor of Law at Institute of Intellectual Property Law of China University of Political Science and Law(CUPL); Vice Chairman of China Intellectual Property Law Society (CIPLS) Member of the Experts Commission of Works of Case Guidance; Research Fellow at the Center for Judicial Protection for Intellectual Property, the Supreme People's Court of the P.R.C; and Visiting Scholar of the University of British Columbia Faculty of Law. Ph.D. (Peking). ORCID: http://orcid.org/0000-0002-5902-7019 The author can be contacted at: fengxiaoqingipr@ sina.com / Address: Institute of Intellectual Property Law, CUPL, No.25, Xi Tu Cheng Road, Beijing 100088, P.R. China.

*** Assistant Professor of Law at Shanxi Normal University; Ph.D. candidate at China University of Political Science and Law. Juris Master (Sun Yat-sen Univ.). ORCID: http://orcid.org/oooo0002-2409-8183. The author may be contacted at: wzxbd@163.com. / Address: School of Law and Political Science, Shanxi Normal University, Linfen City, 041000, Shanxi Province, P.R. China. 
Keywords: TPP, China, Countermeasures, International Environment, Local Elements, Intellectual Property

\section{INTRODUCTION}

As nicknamed as the "Economic NATO Agreement,"1 the Trans-Pacific Partnership Agreement ("TPP") was formerly known as Trans-Pacific Strategic Economic Partnership Agreement. It was originally prepared by the members of Asia-Pacific Economic Cooperation ("APEC") Meeting, including New Zealand, Singapore and Chile as early as in 2002. After the five-year period negotiation, on October 5, 2015, twelve TPP member countries reached a final agreement on the Ministerlevel Conference in Atlanta, the US. ${ }^{2}$ This indicates that the US-leading TPP negotiation has come to an end, reaching unilateral and refined rules in various subjects like investment and intellectual property ("IP"). As a major regional project in the contemporary world, the TPP negotiations have made substantial breakthrough. A huge economic circle covering 40 percent of global economy will be emerging out of China.

TPP will be advancing the traditional mode of free trade agreement ("FTA"); it comes to a comprehensive FTA involving all goods and services. Such partnership agreement could reboot the Asia-pacific economy by integrating the overlapping member States which belongs to the two regional economic cooperation organizations such as the APEC and the Association of Southeast Asian Nations ("ASEAN"). TPP will be a cornerstone of an Asia-Pacific free trade zone covering almost all members of the APEC. It is also regarded as a small World Trade Organization ("WTO") in this region.

As the biggest developing and the most populous country in the world, China will be thus all-round of TPP. Among them, this research will tackle the effect of TPP on IP in China and China's countermeasures. This article is divided into five parts including a short Introduction and Conclusion. Part two will briefly expound the main content of TPP, including the contents with regard to IP. Part three will analyze the strategic choice of the US in joining TPP, the reason why China is ruled out by TPP, and TPP's impact on China's IP system. Part four will discuss the proposed countermeasures in construction of IP system for China against TPP. 
In Conclusion, the authors will point out that China's development is conducive to the world and the international community should neither arm TPP as a 'spear' against China, nor make it a shield to prevent the entry of China. Without China, TPP cannot be a perfect regional agreement; win-win results can be achieved only by mutual cooperation.

\section{MAJOR CONTENT OF TPP}

\section{A. General}

TPP is a comprehensive free trade agreement with 30 chapters, covering almost all trade and trade-related issues. As to trade in goods, the standard raises higher than before. It regulates general products trading ${ }^{3}$ including, e.g., woolen and clothing products. ${ }^{4}$ Trading regulations also cover products origin, customs management and trading facilitation, sanitation and SPS regulation, technological trade barrier, and trading remedy. ${ }^{5}$

As to the aspect of investment, TPP regulates fundamental protection on investment related to other investment agreement. Specifically, it prohibits: non-public purpose charge without just procedure and compensation; local elements, technology customization and other achievements requirement; and free appointment of higher level management agents without the nationality restriction as well as the free movement of investment. ${ }^{6}$ TPP also regulates the cross-border service trading, financial service, temporary entry of business agents, e-communication, and e-business. ${ }^{7}$ As regards national behaviors, it provides government procurement, competition strategy, state-owned corporation, specialized monopoly, employment, environment, cooperation and capability building, unilateral regulations, transparency and anti-corruption, administrative and organization provisions. ${ }^{8}$

TPP considers 'strategic cooperation' in various fields such like IP, labor standard, environment criteria and promotion of the development of small and medium-sized enterprises, etc. ${ }^{9}$ In addition, TPP is involved in financial regulation, competition policy, economic legislation, market transparency, anti-corruption and other fields. $^{10}$

TPP's original goal was to reduce the customs duty between members to zero 
by 2015 , but this target is proposed to be reached in the future. ${ }^{11}$ It is committed to establishing commodity market and service trade market which can be accessed freely by the member countries with the abolition of all customs tariffs and other non-tariff barriers to trade. Regarding trade in goods, the Agreement particularly requires the parties to implement unconditional and non-exceptional measures about zero tariff.

\section{B. TPP on Intellectual Property}

The IP protection of TPP is based on the Trade Related Intellectual property Rights agreement (hereinafter TRIPS agreement). The level of protection is, however, further improved and some contents are just to highlight the TRIPS

agreement. ${ }^{12}$ Overall, the US proposal for IP protection is higher than other FTAs because IP is the magic key to maintaining American dominance in international trade.

\section{The US STRATEGY FOR TPP AND ITS IMPACT ON CHINA}

The 'intellectual property' chapters of TPP covers general principles, cooperation, trademark, geographic indications, patent, undisclosed experiment and other data, industrial design, copyright and related rights, IP enforcement, ISP, trade secret, and other forms of intellectual property as well as members cooperative projects. To explore the comprehensive influence of TPP on China, it is necessary to study the strategic choice of the US to join TPP.

\section{A. The Strategic Choice of the US towards TPP}

The US pushed TPP in order to stimulate the domestic economy in the changing global economy; to share the booming growth in Asia; and to control the trade system in Asia-pacific region. Strategically, the US is hoping to reduce the influence of China in the economic integration of Asia. ${ }^{13}$ The rapid rise of China in recent has made the US uneasy. ${ }^{14}$ Actually, the US took the APEC as its strategic grounding politically as well as economically in this region. Because of the functional limitation of the APEC as a loose forum, however, the US might 
keep eyes on the value of TPP to establish a US-led multilateral cooperation system in this region. ${ }^{15}$ The US presumably hoped to create a new Asia-Pacific order based on free trade area, replacing the " $10+3$ ", " $10+6$," or even APEC comprehensively. TPP could be regarded as the core of this new era of the US. ${ }^{16}$ Just after the TPP agreement was reached, the US President Barack Obama stated:

\begin{abstract}
Over the summer, Democrats and Republicans in Congress came together to help the United States negotiate agreements for free and fair trade that would support our workers, our businesses, and our economy as a whole. When more than 95 percent of our potential customers live outside our borders, we can't let countries like China write the rules of the global economy. We should write those rules, opening new markets to American products while setting high standards for protecting workers and preserving our environment. ${ }^{17}$
\end{abstract}

His remarks indicate that the US actually feels the danger. It is generally recognized among the Chinese that TPP is a major economic platform of the US for its Asia-Pacific strategy.

\title{
B. Why is China out of TPP?
}

China, as the region's largest trading nation, has not joined TPP. David Pilling pointed out that TPP without China is quite an omission. ${ }^{19}$ The authors would further argue that TPP is the trade version of the Obama's "Return to Asia" strategy. There are also queries about "behind the border" issues of TPP. ${ }^{20}$

Another reason to rule out China is that "Beijing, slighted by its exclusion, may be goaded into reforming its economy so it can join at a later stage." ${ }^{21}$ It does not make sense, however, because China's position to globalization is unswerving and firm. TPP may be designed for the benefit of American corporations. ${ }^{22}$ The US itself takes the double standard position. Actually, the Obama administration denounced the trade agreements which would cause manufacturing jobs to go overseas. David Pilling said: "Even if TPP is finally concluded, it will be too watered down to satisfy trade purists and too intrusive to please Washington's Pacific partners." ${ }^{23}$ The US tries to establish new game rules and a new club through TPP. With the advantage of TPP, the US could undermine the $10+3,10$ +6 and the APEC $^{24}$

Meanwhile, TPP requires that any country to join the talks must attend the 
negotiations in 'all' fields and the entry of new member must be subject to the unanimous consent of all members. It would be difficult for some countries to join it when they are not fully competitive in certain areas. It shows that the higher standards of TPP not only conforms to the American interests, but also raises the threshold for new members. TPP cannot be fully implemented only by unilateral efforts of American overnight. Furthermore, due to the exclusion from TPP, China would lose an effective and reasonable opportunity to improve the level of market opening. In short, exclusion of TPP does not comply with the strategic interests of China with regard to joining regional free trade organizations. ${ }^{25}$

\section{Impact of TPP on China}

\section{Macro Impact of TPP on China}

TPP will have a profound impact on China in politics as well as economy. In politics, it will isolate China and weaken its influence in the Asia-pacific region and the world. China's future strategy will have to be confined within a limited purview. Staying outside of TPP would lead to a loss of opportunities for China to establish further comprehensive cooperation with the countries in Asia-Pacific region. In economy, China would not sustain the current status in the global market out of TPP, considering its higher liberalization standard and wider free trade area than other FTAs.

If joining TPP, China should consider the following factors as: (1) economic sovereignty; (2) state-owned corporation; (3) employment protection; (4) environmental standard; and (5) intellectual property.

As mentioned above, TPP prohibits confiscation without fair procedure and compensation. A main objective of TPP is to enable investors to sue the members' government in international court with respect to confiscation, investment treatment, IP, and even policy or statute of one member. Obviously, TPP has transplanted the NATFA provisions. Its investment rules and dispute resolution between investors and member States, however, would bring about significant challenge of economic sovereignty to most developing countries including China.

'Confiscation' is a general right that most developing countries strived to have in the past. It should be, however, followed by certain compensation to the relevant parties. 'Sovereignty' is the supreme and core value for every country. China focuses on economic sovereignty as principle in the process of international 
trade and transaction. If hoping to join TPP, China should accept all these strict provisions because TPP not only exceeds the WTO area, but requires all signatories to abide by the agreement. China must compromise even sovereignty with TPP. It is, however, unimaginable to China.

China's state-owned corporations have been increasing the general and monopoly power for the past twenty years. China may have to privatize some state-owned corporations in order to join TPP. To China, however, state-owned corporation is the backbone of national economy. Privatization would demand distributing current wealth so that China would not let it happen.

TPP provides the employment regulations including the environmental condition, the value of workers, and humanity care. ${ }^{26}$ Although Chinese workers have recently enjoyed better working condition with higher income, the general employment protection in China is not satisfying the relevant regulations of TPP. In addition, trade union is not actively working for the employment protection in China which is mandatory to join TPP. Development of national economy and social progress would not be obtained within short period.

Environmental protection is a green barrier. Since the "reform and open-door policy," China's economy has been growing significantly. In this course, however, economic development delivered many environmental questions which cannot be solved shortly, either. Although the environmental protection refers to carbon output ratio, China barely meets the advanced standard of developed countries. TPP deeply concerns environmental protection. ${ }^{27}$ It will be a great challenge to China, too.

TPP contains some other standards which have been proposed by the US in order to set up new means of global trade. But they can be easily accessed by China shortly. ${ }^{28}$ Barack Obama said: "TPP will create a trade agreement at a high level; potentially it applies not only to Asia-pacific region but also all over the world. ${ }^{29}$ Without signing those agreements, China's trade volumes to these countries would be reducing.

TPP is a completely open and highly liberalized institution which can promote trade, investment as well as employment. Without joining TPP, China would miss political and economic footing to be more globalized. ${ }^{30}$ As above mentioned, however, China will face substantial barriers to TPP. Today, China is in a dilemma: not join with substantial losses, or join with difficult barriers. 


\section{Influence on the Intellectual Property System of China}

China is not a founding member of the TPP. If China wants to join the TPP, it should be then subject to already established rules of the Agreement, especially in IP. The gross GDP of the 12 TPP members accounts for about 40 percent of the world total. ${ }^{31}$ As the trade in technology including IP will take up a large proportion in the future, without TPP, China could be isolated from the world's IP market, thereby suffering huge loss. The US might propose TPP negotiations in order to sidestep the counterproductive effects from the WIPO and the TRIPs agreement. As a result, the US can do everything at will outside the WIPO and TRIPs agreement. Instead, it is trying to establish the global IP system with restrictive standard, which eventually forge American distinctive advantages in intellectual property.

TPP's proposed measures for the IP protection are so comprehensive that almost every discipline seems to be included. The protected disciplines cover trademarks, geographical indications, patent, Internet domain names, copyright and its related right, encrypted satellite and cable program, agricultural chemicals, medicines, commercial secrets and many other objects of intellectual property. ${ }^{32}$ Some are available upon request for relief, while others may be conducted by investigation. Some researchers even assert:

\footnotetext{
By combining a huge number of international intellectual property conventions and the best practices relevant to the national protection of the intellectual property, TPP has specified the objects of intellectual property to be managed and protected by laws, which will greatly push the development of international regulations about the protection of intellectual property. A new international standard of protection of intellectual property may even come into existence. ${ }^{33}$
}

TPP involves international conventions including the TRIPS agreement and requests the parties to approve or join before the Agreement takes effect. ${ }^{34}$

In trademark registration and management, TPP has not only lowered the requirements for trademark registration, but also expanded the registered trademark subject matter. ${ }^{35}$ Also, trade mark registration is no longer binding to perceivable requirement so that sound, smell and geographic indication can be registered as trade mark.

TPP also offers the maximum protection to well-known trademarks. According 
to Decision regarding the Modification of the Trademark Law of the People's Republic of China, China launched the third revision of the Trademark Law on August 30, 2013. ${ }^{36}$ The revised law came into force on May 1, 2014. It is a big step forward. Following the revision, trademark in the form of sound can be registered, but there is still no rule about registration of trademark in the form of 'smell.' Thus, it is still far from the TPP standard about registration of the new trademark in the form of 'smell.' In addition, in the trademark application in electronic form and protection of well-known trademark, TPP is advanced more than the regulations in China's existing laws. TPP provides that any party shall not require the conditions for the trademark to be licensed. ${ }^{37}$ But, Article 43, paragraph 3 of China's Trademark Law provides that if any person allows other people to use the registered trademark, the licenser shall submit the licensing to the trademark office for filing and make announcement through the trademark office. There is still gap between China's Trademark Law and TPP.

According to Article 18.63 of TPP, the copyright term should not be less than 70 years after the death of author. If the work is created by organization, the copyright term should be not less than 70 years after the first publication, performance, or recordation. If the work is created, performed, or recorded without publication within 25 years, its copyright term should not be less than 70 years after its creation, performance and recordation. Therefore, the period of protection for copyright is extended from 50 years after death on the basis of natural life to 70 years. It has unified the principles of protection for the copyrighted works in any form of photocopying. TPP provides that members must protect works, performance, recordation such as song, movies, books, and software, and criminal penalty on circumventions on technology measures. It also requires members to explore the balancing method on copyright in digital environment. China's regulation has a substantial gap against TPP's copyright regulation. ${ }^{38}$

In the area of trade secret, TPP requires members to provide legal measures in order to preclude illegal infringement on trade secrets, and set forth criminal procedure and penalty on various kinds of trade secret infringement, including internet theft and illegal snap. ${ }^{39}$

In terms of patent, TPP set up a new standard related to medicine production. Members should provide necessary protection to undisclosed experiments, new medicine, or agriculturally chemical products for the entry into market. ${ }^{40}$ TPP 
emphasizes that all inventions should be granted the patent regardless of product or process. ${ }^{41}$ According to TPP, although members could preclude patent on diagnosis on human being or animals, treatment and surgery, non-microorganism, method of producing plants and animal from non-biological substance or microorganism, they could offer patent on method of producing from plants and animals with microorganism and non-biological aspect, which expanded the patentability of innovation and increased the number of objects of patent right. However, Article 25 of the Patent Law of China provides that method of diagnosis and treatment of diseases, animal and plant species cannot be granted a patent. Additionally, TPP makes definition on 'New Medicine' with new protective term, and offers several years' exclusive rights on undisclosed data. ${ }^{42}$ TPP demands members removing administrative barriers for the new medicine to enter into markets. It regulates that members should prohibit others from producing new medicine within 5 years after the official sales under the new protection term. ${ }^{43}$ As to the biological products, especially, TPP requires members to prohibit the making by others within 8 years after the official sales; members should provide the biological product with 5 years' protective term so long as they are able to offer other measures which reach the equal market effect. ${ }^{44}$ This clause may cause controversy because many developing countries are concerned that enhancing protection of medical patent will lead to the soar of prices for domestic drugs as well as deterioration of environment for medical insurance. Today, China is able to copy some medicine product. Obviously, this single aspect can preclude China from TPP, substantially affecting the oversea market to China's medicine industry.

TPP aims at establishing powerful IP enforcement measure, including civil and criminal procedure, temporary and border measures, and penalty. TPP also makes more transparent and favorable measures to crack down on counterfeit and piracy. Strict punishment is, however, more advantageous to developed countries.

TPP has further expanded the scope of IP protection, which would be getting more strengthened according to the international trend. Any violation of the Agreement will be subject to corresponding punishment. ${ }^{45}$ It will protect IP further in international level. ${ }^{46}$

Intellectual property must be protected. However, overprotection would lead to the counterproductive effect. In IP field, most of the least developed and developing countries are fully dependent on the TPP member States most of 
whom are developed countries. They may thus lose the chance to compete with them for overprotection. These will do harm the IP system of China which is globalizing. Today, China is constantly improving the level of IP protection. E.g., China has established three independent IP courts, ${ }^{47}$ so that its IP protection is getting stronger these days. China and other developing countries require a proper level of IP protection.

\section{Countermeasures for China Against TPP}

\section{A. China's Economic Sovereignty}

According to TPP, the IP dispute resolution will be applied to all TPP disputes including investment. If the TPP dispute mechanism contains investors and countries, then TPP's real breakthrough is the bilateral "Investor-State Dispute Settlement" to multilateral mechanism. As mentioned above, TPP will impose challenges to China in two aspects: one is the state-owned corporation or confiscation; the other is the dispute resolution between investors and member countries. Sovereignty is a general principle in international economic interaction. China is unlikely to give up such principle in the process of extraterritorial communication. It might prevent China from reaching a free trade agreement with the US. Two questions may arise here. (1) Whether China can make IP investment as state-owned or confiscation? (2) Whether foreign investors can sue the Chinese government when dispute occurs in an international court before exhaustion of all remedies? Without state-owned corporation or confiscation power, China would regard the investor-state dispute ("ISD") mechanism as the indication of losing economic sovereignty.

China has never conducted the state-owned or confiscated power over foreign investors since the reform and open door policy came into force. Did China abandon such power then? The answer is negative. China still retains such power because it is necessary for China to balance foreign powerful capitals.

Suing the Chinese government is to make a court above the Chinese sovereignty. Such rule seems fair, because all TPP countries must abide by their own regulations. However, it is unfair in nature. What if Xiang Liu, a famous athlete of $110 \mathrm{~m}$ high hurdles competes with a ten-year's old boy with same rules and fair standard? In 
IP and cross-border investment, China does not have the equal power to developed countries like the US.

China should tackle the have-to-do issues on sovereignty regarding the institutional construction of intellectual property. China should keep reforming state-owned corporation system; it should gradually reduce or remove the compensation to corporations in order to increase its competency and fairness. Suaihua Cheng, Executive Director of International Center for Trade and Sustainable Development (“ICTSD”) says:

\footnotetext{
China shall establish 'competitive neutrality' rules on the market for state-owned enterprises, such as the elimination of long-term political advantage and market dominance enjoyed by state-owned enterprises, so as to create a fair competitive market environment. According to the current standard of TPP agreement, once the Chinese state-owned enterprises participate in TPP member states linking to the value chain, the way they operate their business will be subject to stringent test. $^{48}$
}

In addition, all corporations should analyze the TPP-related IP rules as well as organize the center for innovation so as to enhance the competitiveness. As to dispute resolution, China should release its own opinion and compromise with TPP members based on sovereignty. Even though China is not joining TPP shortly, the economic sovereignty should not be sacrificed.

China has a vast market and strong trade networks with TPP members like the US and Japan. However, China will gradually realize that the TPP rules preclude non-member countries. So long as Chinese market is expandable, it can make up for all weaknesses in foreign trade. As competition relies on capability, China should improve itself as the priority. If increasing the innovative capability and developing IP with better and faster pace following global standards, all unfair conditions and regulations under the TPP will be solved.

\section{B. China's Own Situations}

There is still significant gap between the situation in China and the requirements of TPP with respect to trademarks, geographical indications, patent protection, copyright protection, etc. In addition, TPP has broadened the scope of infringement, the amount of compensation for the damages, the conditions 
applicable to infringement, the scope of the infringed contents and enforcement at the border, and legal enforcement of infringing goods. TPP may be a new Anti-Counterfeiting Trade Agreement ("ACTA"). Both ACTA and TPP require that participants authorize the departments concerned in order to take action against the commercial infringement even when the right holder does not apply. ${ }^{49}$ TPP intensifies criminal punishment regardless of direct or indirect motive for economic benefits. According to ACTA and TPP, legal enforcement procedure should be applicable to the infringement in trademark right and copyright in digital environment. ${ }^{50}$ As part of the rule making, it has become an essential content in various free trade agreements. In the process of establishing various FTAs, developed countries continue to set up the standards for IP protection and enforcement, so that developing countries and least developed countries cannot enjoy the benefits of trade liberalization in other ways. The strategy to take them is to join the negotiations. They could either protect this field firmly, or improve the IP standard in a passive way under the pressure of "carrot and stick."

In the course of integrating regional economy, modification of IP system is an unavoidable issue for China. The multiple revisions of the patent law, trademark law, and copyright law show that China is getting accustomed to the rigid international standards for IP protection. The third modification of Copyright Law and the fourth revision of Patent Law currently going on in China are strengthening the penalties for infringement by administrative enforcement and judicial measures. ${ }^{52}$

China has made substantial achievement in the acquirement, protection, and exploitation of intellectual property. It is, however, undeniable that China is still behind the developed countries in this aspect. As the TPP negotiations were over, the gap would gradually become bigger. Actually, the IP chapter of TPP is most controversial because it has significant effect upon Internet, medicine area, publication, and basic human rights, biological patent, and trade mark. TPP can be deemed as an advantageous agreement to the prevailing party. As to medicine production, multilateral medical companies will monopolize the productions which naturally raise medicine prices in the world.

Comparing TPP to China's IP protection system, China's specific condition should be fully considered when initiating and modifying related law and policy. Some regulations can be modified following the TPP standards such as IP 
protection measure or degree, while others may not reach the requirement. Also, it should be improved gradually. We can seek for alternatives, such like the IP dispute resolution. It would not only protect China's sovereignty and benefits, but also solve the problem.

\section{Promotion of Negotiations on Free Trade Agreement}

In order to satisfy TPP member countries regarding IP, China should pay special attention to the role of the ASEAN, the trilateral free trade agreement among China, Japan and South Korea, and the Regional Comprehensive Economic Partnership ("RCEP"). Also, potential impact of adverse factors in regard to the IP issue in TPP should be eliminated. Simultaneously, China should proactively participate in the WTO and the WIPO for dominating multilateral trade system and imposing indirect influences on TPP. It could lead China to hold the strategic initiative against the developed countries. ${ }^{53}$ Once RCEP is built, it will be significant for China to start bilateral, multilateral, regional and sub-regional cooperation. In this course, China will consider the national interests first. In order to comply the national economic interests with the requirements for IP principles of TPP, China should carefully and technically analyze the relevant legal text. It will help China to understand not only the new trend of maximum international protection for intellectual property, but also the specific interests. ${ }^{54}$

In these respect, China should take measures on IP and other negotiations so as to support each other. China should rely on 'free market' as its economic foundation. TPP will impose great impact upon China's economic and political ground. Regional trade agreement is inevitable in spite of its high standard. As long as China actively adopts various bilateral or regional trading arrangements based on equal and beneficial aspect, China will make substantial achievements. In different negotiations, China should play the active but unaggressive role. So long as all parties regard China as a reliable, dependable, considerable, and beneficial trading partner, China can achieve better regional trading arrangement, and eventually remove the counterproductive effects from TPP agreement.

\section{Improving the Intellectual Property Power}

To counter the challenge and impact from TPP, China must keep on improving the IP industry. Since the "reform and open door" policy, China has made substantial 
achievements in IP. However, it should keep on improving hard as well as soft power in this industry. In terms of hard power, China should invest more on education and scientific research. Although China's economic scale has reached the second in the world, it is yet lack of sufficient investment in education and R \& D. Education is a firm base of advanced research. The government should invest more on their research projects to enhance hard power in IP industry. In terms of soft power, meanwhile, China should enact the new laws and adopt appropriate policy in this field. The soft power for IP also relates to culture and atmosphere. China should develop IP culture and atmosphere by promoting social consensus on innovation and creativity. Today, Chinese society is much more interested in knowledge-based economy than before. It will have influence on developing science and technology in connection with IP industry.

\section{E. Intellectual Property as a Prior National Strategy}

Based on Nation's Inner strategy, China should improve IP institution and system, reinforce IP protection and exploitation, and facilitate the building of innovative country. In spite of substantial social and economic progress, China's economic structure is not highly advanced yet. Currently, China is devoting itself to constructing 'innovative' country with the national IP strategy. IP protection is demanded for more development of national economy. Today, China is analyzing the general contents of TPP on IP, both theoretically and practically.

Therefore, China should keep IP on priority in its development plan. The IP chapter was most dramatically adopted in the TPP negotiations. China should get advantages in the IP negotiation.

\section{F. OBOR and New Market}

TPP might preclude China to weaken its influence on Asia-pacific or even the world. China realized such intention in advance and proposed the "One Belt, One Road" ("OBOR") initiative. ${ }^{55}$ Two leading TPP members - the US and Japan - have not been invited to OBOR. Indeed, it significantly weakens the negative impact of TPP on China. Current Chinese position is similar to that of the 18th-19th century's UK who just began developing its maritime power. The then UK had to switch for the sea. The "Belt and Road" initiative would be a countermeasure to TPP. Assume that TPP establishes its own rules, without China. 
China's trade and commerce will bear substantial losses which would be a great threat to its national security eventually.

China can negotiate with each member of TPP respectively to reach bilateral agreement. China and the TPP member countries are trade partners. If they need more benefits through trade and commerce, then they will make another network.

\title{
G. Constant Adaptation to the TPP Rules
}

Suaihua Cheng points out:

\begin{abstract}
TPP member countries in global value chains may require higher performance standards in products, the environment and labor. Although China is not a TPP member, as the supply side, it must also meet these standards. In large multinational group controlled by the global supply chain, the upstream enterprises of the Chinese enterprises as well as the downstream business partners may be TPP member countries. That is, whether or not China is a member of TPP, the commercial operation of Chinese enterprises must be close to TPP's high standards. Otherwise, they will be kicked out of the global value chain. ${ }^{56}$
\end{abstract}

China can make a series of reform measures to meet the TPP requirements within several years. In a short term, China is more likely to give up TPP negotiations because it may not be ready to perform the obligations of TPP. China should thus develop its domestic economy enough to join the US-led "comprehensive and equal" trade agreement. ${ }^{57}$ Prior to joining TPP, China should actively participate in regional trade. Considering the ability to carry out reform, it is just a matter of time for China to become a member of TPP.

TPP can be regarded as a steppingstone of building the Free Trade Area of Asia-Pacific ("FTAAP"). China's participation in TPP at the proper time is thus productive to implementing its plan of setting up FTAAP as a whole. Eventually, it will help to hit the balance of the power in this region. ${ }^{58}$ However, this process will be painstaking. It is necessary for China to consult each TPP member one by one and obtain consent of all members by satisfying their conditions. In the future, China should pay close attention to the progress of TPP negotiations, actively promoting the grand design of FTAAP. At present, both TPP and RCEP are considered as the parallel paths of regional economic integration through FTAAP. In the long term, the US and China could make compromise between TPP and 
RCEP. FTAAP would be a good arrangement to establish the connection between the two economic powers. ${ }^{59}$

For China, TPP is an opportunity rather than challenge. China should join negotiations timely and positively instead of isolation. TPP is much-maligned in terms of labor, environmental and IP issues. Take the labor and environmental protection for example! To date, China has made great efforts to upgrade the related laws and regulations, but the effect is not so optimistic. It is mainly due to the local administration's slacking in the enforcement of labor and environmental laws and the lack of media control. To strengthen the rule of law will be the right way in this respect. Given that TPP is formulating new IP rules, China should also have relevance. China should reform the system in order to follow the TPP negotiation process, thereby minimizing the gap between China and other developed countries.

The ultimate goal of the US is not TPP. TPP is a 'detour' approach to conclude its final goal of FTAPP by levering the trade liberalization outside the APEC. It is just an 'entrance' to the grand free trade agreement dominated by the US. ${ }^{60}$ To achieve this goal, the US will expand TPP. Without the participation of China, however, FTAPP will not be fully influential.

\section{Conclusion}

If completed, TPP will be the major economic platform for the Asia-Pacific Strategy of the US. The Americans will consolidate the core leadership in the Asia Pacific region. It will compete with China for the integration of East Asia. TPP will have a far-reaching impact on China's politics, economy and society as well as IP system. In politics, TPP will exclude and isolate China in the AsiaPacific region and even the world so that the future strategy of China would be constrained within a closed space. In economy, China's growth will be restrained. In IP, especially, China has faced another barriers for globalization. As to the countermeasures, China should research it more at home and abroad and participate in the negotiations for free trade agreement actively. China is also required to improve the relevant IP laws to meet the TPP conditions.

Recently, some foreign countries are very much concerned about the development 
of China. "Threat of China" and "collapse of China" are often referred to in the global society. It is a fearful antipathy to the rise of China. ${ }^{61}$ In fact, the development of China with a quarter of the world population will be a great contribution to the global economy rather than threat to the rest of the world. Therefore, China should cautiously persuade its partners such as the US to eliminate prejudice against China. The international community should neither arm TPP as a 'spear' to contain China, nor make it into a shield to prevent China from entering the world. Without China's participation, TPP cannot be a perfect regional institution. As a member of the WTO, ${ }^{62}$ China is working together with other free enterprise countries. Considering the expanding influence of China's economy, the best option is to accept China to TPP. China and other countries can achieve a 'win-win' outcome through cooperation and compromise.

\section{REFERENCES}

1. Atul Aneja, China and U.S. Set to Grapple for Regional Space during APEC Summit, available at http://www.Thehindu.com/news/international/china-and-us-set-to-grapple-for-regional-spaceduring--summit/article6580366.ece (last visited on Aug. 7, 2016).

2. See TPP Broad Agreement Reached, available at http://www3.nhk.or.jp/nhkworld/english/ news/onbusiness/20151005.html (last visited on Aug. 7, 2016).

3. TPP chs. $2 \& 3$. Chapter 2 is about national treatment and market access for goods, and Chapter 3 is about rules of origin and origin procedures. Those are general products rules.

4. Id. ch. 4 (Textile \& Apparel Goods).

5. Id. chs. $3 \& 5-8$.

6. Id. arts. 9.8-9.11.

7. Id. chs. 10-14.

8. Id. chs. $15-17,19-21 \& 25-27$.

9. Id. chs. $18-20 \& 24$.

10. Id. chs. $16 \& 26$.

11. Hongqiang $\mathrm{Xu}$, The Latest Progress and Prospect of the TPP Negotiations [TPP 谈判的新 进展和前景展望], available at http://www.drc.gov.cn/n/20130829/1-224-2876091.htm (last visited on Aug. 7, 2016).

12. TPP art. 18.63 (Term of Protection for Copyright and Related Rights).

13. Supra note 11.

14. Id.

15. Gao Lan, Characteristics of Development and Its Impact on the TPP Strategy in Japan [日本TPP 
战略的发展特征及其影响] <available only in Chinese>, 6 WorLD ECONO. STUD. [世界经济研究] 76 (2011).

16. For details, see H. Clinton, America's Pacific Century, Foreign Pol'y, Oct. 11, 2011, available at http://foreignpolicy.com/2011/10/11/americas-pacific-century (last visited on Aug. 7, 2016).

17. See Statement by the President on the Trans-Pacific Partnership, The White House Briefing Room, Oct. 5, 2015, available at https://www.whitehouse.gov/the-press-office/2015/10/05/ statement-president-trans-pacific-partnership (last visited on Aug. 7, 2016).

18. Jinping Zhao, Trans-pacific Partnership Agreement: Influence and China's Countermeasures [跨太平洋伙伴关系协定: 经济影响与对策] 42 (2013).

19. D. Pilling, Round two in America's battle for Asian influence, Fin. Times (Chinese ed.), Apr. 3, 2015, available at http://www.ftchinese.com/story/001061384/en (last visited on Aug. 7, 2016).

20. Lian Xiao \& Hongru Wang, Who is Leading the New Way of Global Trade? The United States Tries to Dominates the TPP to Build Another WTO [谁在引领全球贸易新方式? 美国主导 TPP 意欲再造一个WTO], 1 ChINA ECON. WeEKLy [中国经济周刊] 37 (2012),

21. Supra note 19.

22. Id.

23. Id.

24. Supra note 20 , at $37-8$.

25. Supra note 18 , at 45.

26. TPP arts. $19.3 \& 19.5-19.8$.

27. Id. arts. $20.3 \& 20.5-20.6$.

28. Supra note 20, at 37.

29. Yuting Sun, Obama Says that the TPP Basic Framework Is Formed and Legal Text to Complete before Next Year [奥巴马称, TPP基础框架达成明年之前形成法律文本], CHINA News [中国新闻], Nov. 13, 2011 <available only in Chinese>, available at http://www. chinanews.com/gj/2011/11-13/3456470.shtml (last visited on Aug. 7, 2016).

30. Supra note18, at 45.

31. Supra note 19 , at 21.

32. Chapter 18 of TPP indicates the protected objects of intellectual property. See TPP ch. 18, sections C (Trademarks); E (Geographical Indications); F (Patents and Undisclosed Test or Other Data/Subsection C: Measures Relating to Pharmaceutical Product); G (Industrial Designs); H (Copyright and Related Rights); and J (Internet Service Providers). See also TPP arts.18.79 (Protection of Encrypted Program-Carrying Satellite and Cable Signals), 18.28 (Domain Names) \&18.78 (Trade Secrets).

33. Fuli Chen, The Latest Development of Strong International Protection of Intellectual Property-the Main Content and Some Reflections about the Intellectual Property Involved in Trans-pacific Partnership Agreement [知识产权国际强保护的最新发展-《跨太平洋伙伴关系 
协定》知识产权主要内容及几点思考], 6 IntelLECTUAL ProperTy [知识产权] 76 (2011).

34. TPP arts.18.1 (Definitions) \& 18.7 (International Agreements).

35. Smell and geographic indication cannot be registered as trade mark in China. See TPP art. 18.18 (Types of Signs that can be registered as Trademarks). It provides: "No Party shall require, as a condition of registration, that a sign be visually perceptible, nor shall a Party deny registration of a trademark only on the ground that the sign of which it is composed is a sound. Additionally, each Party shall make best efforts to register scent marks."

36. The third revision of the Trademark Law was adopted on August 30, 2013 at the 12th Session of the Fourth Meeting of Standing Committee of the National People's Congress, available at http://www.gov.cn/jrzg/2013-08/30/content_2477825.htm (last visited on Aug. 7, 2016).

37. TPP art. 18.27 (Non-Record of a License).

38. Id. art. 18.63 .

39. Id. art. 18.78 .

40. Id. arts. 18.48-18.52.

41. Id. art. 18.37.

42. Id. arts. $18.50-18.53$.

43. Id. arts. $18.50-18.52$.

44. Id. art. 18.51.

45. Supra note 33, at 77.

46. Id. at 78 .

47. In 2014, China set three independent intellectual property courts, namely, Beijing Intellectual Property Court, Shanghai Intellectual Property Court, and Guangzhou Intellectual Property Court.

48. Shuaihua Cheng, A World with PPT: China's Response [一个 TPP 的世界: 中国的应对] <available only in Chinese>, available at http://blog.sina.com.cn/s/blog_61ca34f10102vyif. html (last visited on Aug. 7, 2016).

49. TPP art. 18.76; ACTA art. 8.

50. TPP art. 18.71; ACTA art. 27.

51. Xia Wei, A Research on TPP High Standard and International Rulemaking from the Perspective of United States' Intellectual Property Proposal [从知识产权协议草案看 TPP 谈 判高标准与国际规则制定], 5 INT'L Bus. RESEARCH [国际商务研究] 74 (2014).

52. Xuefeng Liu, Xing Gao \& Peng Liu, A Study on the Influence of Intellectual Property Clauses in Trans-Pacific Partnership Agreement on China and Countermeasures [《跨太平 洋伙伴关系协定》(TPP) 知识产权条款对中国的影响及其对策研究], 2 F. ON SCI.-TECH IN CHINA [中国科技论坛] 117 (2014).

53. Lixian Cong, The influence of negotiations about intellectual property in the Trans-pacific Partnership Agreement on China and the strategies [《跨太平洋伙伴关系协议》知识产权谈判 对我国的影响及其应对策略], 5 INT’L F. [国际论坛] 80 (2014). 
54. Liu Yu, Analysis on the New Development of TPP's International Maximum Protection of Intellectual property -Taking Some Rules of Copyright as the Point [TPP 知识产权最大化国 际保护新发展析论-以著作权若干规则为切入点], 4 BeIJng U. SCI. \& TECH. J. (SoCIAL SCI. ED.) [北京理工大学学报 (社会科学版)] 128 (2014).

55. "One Belt and One Road" means "the Silk Road Economic Belt and the 21st-Century Maritime Silk Road." On Sept. 7, 2013, President Xi Jinping delivered a speech at Nazarbayev University in Kazakhstan, suggesting that China and Central Asia join hands to build a Silk Road economic belt to boost cooperation. On Oct. 3, 2013, Xi said in a speech at the Indonesian Parliament that China and the ASEAN would promote maritime cooperation and build a 21st-century maritime Silk Road. Later, its official translation in English is "The Belt and Road initiative." For details, see Yearender: New diplomatic concepts raised by China, ChinA DAILY, Dec. 28, 2014, available at http://www.chinadaily.com.cn/china/2014-12/28/ content_19185354.htm; One Belt, One Road may be shortly abbreviated as B\&B in English [一带一路” 终于有了官方英译：简称 “B\&R”], CHINA DAILY, Sept. 23, 2015, available at http://www.chinadaily.com.cn/hqcj/zgjj/2015-09-23/content_14211761.html (all last visited on Aug. 6, 2016).

56. Supra note 48.

57. Los Zetas \& Basu Das, Containing China by the TPP: Myth or Reality? [用 TPP 遏制中国: 神 话还是现实?], in RESEARCH ON THE TPP AND Asia-PACIFIC ECONOMIC INTEGRATION [TPP 与亚太 经济一体化研究] 272 (Guoqiang Tang ed., 2013).

58. Supra note 54, at 128.

59. Supra note 57, at 272.

60. Zhankui Gong, Asia-Pacific Regional Economic Cooperation Report 2013 [亚太区域经济合 作发展报告 2013] 322 (2013).

61. See CHINA: One big threat, Coeur D’Alene Press, July 8, 2016, at A4, available at http:// cdapress.com/opinion/letters_to_editor/article_de2e1432-449e-11e6-82cd-8350167216c6. html; Gordon Chang, China in Big Trouble, Could Bring Global Economy Down with It, ECon. J. Insight (HK), Mar. 22, 2016, available at http://www.minyanville.com/businessnews/markets/articles/gold-precious-metals-investing-china/5/13/2016/id/56994 (all last visited on Aug. 7, 2016).

62. On November 10, 2001, the WTO Fourth Ministerial Conference has deliberated the application of China to enter into the WTO, and China officially becomes a WTO member from December 11, 2001. 
